\title{
E1A-mediated suppression of EGFR expression and induction of apoptosis in head and neck squamous carcinoma cell lines
}

\author{
Marcella Flinterman ${ }^{1}$, Joop Gäken², Farzin Farzaneh ${ }^{2}$ and Mahvash Tavassoli*,1 \\ ${ }^{1}$ Head and Neck Oncology Group, Department of Oral Medicine and Pathology, King's College London, The Rayne Institute, 123 \\ Coldharbour Lane, London SE5 9NU, UK, ' Department of Molecular Medicine, Guy's King's \& St. Thomas's School of Medicine and \\ Dentistry, King's College London, The Rayne Institute, 123 Coldharbour Lane, London SE5 9NU, UK
}

Previous studies have shown early region 1A (E1A) gene to inhibit the proliferation of tumour cells with wild-type, but not mutant, p53. E1A has also been shown to downregulate c-erb-B-2/neu expression, resulting in inhibition of growth in c-erb-B-2/neu overexpressing tumour cells. In this study, we have investigated the effect of E1A expression on four head and neck squamous cell carcinoma (HNSCC) cell lines that do not overexpress c-erb-B-2/neu. Cell cycle and Western blot analysis show E1A-mediated induction of apoptosis in all cell lines examined. This induction of apoptosis was independent of the p53 status as it occurred in the cell lines with wildtype, mutated or deleted p53. However, there was no evidence of E1A-induced apoptosis in a $\mathrm{p53}^{+\mathrm{ve}}$ normal human fibroblast cell line, 1BR3. Analysis of apoptosis in the SCC cell lines demonstrated E1A-mediated downregulation of EGFR, which was overexpressed in each of these cell lines. Overexpression of an exogenously introduced EGFR, under the control of an E1A-insensitive heterologous promoter, blocked E1A induction of apoptosis in these cells. Therefore, E1A-mediated downregulation of EGFR expression appears to be the cause, rather than a consequence of $\mathrm{E} 1 \mathrm{~A}$-induced apoptosis in these SCC cell lines. Previous studies have shown downregulation of EGFR expression by PML. Interestingly, E1A expression in the HNSCC cells altered the pattern of PML distribution and induced the level of PML protein, thus suggesting that E1A-mediated downregulation of EGFR may occur via direct or indirect interactions with PML. These findings demonstrate a novel pathway by which E1A can induce apoptosis and identify EGFR as a potential target for the development of therapeutic strategies against epithelial malignancies, the majority of which have abnormal EGFR expression.

Oncogene (2003) 22, 1965-1977. doi:10.1038/sj.onc.1206190

Keywords: E1A; EGFR; PML; apoptosis; head and neck cancer; gene therapy

*Correspondence: Dr Mahvash Tavassoli;

E-mail: mahvash.tavassoli@kcl.ac.uk

Received 22 August 2002; revised 23 October 2002; accepted 24 October 2002

\section{Introduction}

The early region $1 \mathrm{~A}$ (E1A) gene of human adenovirus type 5 is essential for adenoviral replication. E1A mRNA is spliced into two forms, $12 \mathrm{~S}$ and $13 \mathrm{~S}$, which code for two major proteins of 243 and 289 residues, respectively (Askusjarvi, 1979; Ferguson et al., 1985). E1A proteins regulate the transcription of several cellular genes, enhancing and suppressing transcription in order to provide a suitable environment for viral replication reviewed in Frisch and Mymryk (2002) (for recent review). E1A activates the transcription of a number of genes including $\beta$-tubulin (Stein and Ziff, 1984), heat shock proteins (Kao and Nevins, 1984), cfos, c-jun, jun B and c-myc (Sassone-Corsi and Borelli, 1987; de Groot et al., 1991). E1A also represses the transcription of several cellular genes including the immunoglobulin heavy chain and the HER-2/neu gene (also called $c$-erb-B-2/neu) and inhibits gene expression enhanced by the simian virus 40 and polyomavirus enhancers (Borrelli et al., 1984). Furthermore, E1A binds and alters the function of several proteins including RB (Whyte et al., 1988), KIPl/p27 (Mal et al., 1996), cyclin A-CDK2, cyclin E-CDK2 (Faha et al., 1993) and p300/CBP (Stein et al., 1990; Thomas and White, 1998). E1A has also been shown to interact with CtBP and activate promoters of several epithelial cell adhesion genes (Grooteclaes and Frisch, 2000). This interaction has shown to be important for the ability of E1A to induce apoptosis in epithelial cells. Expression of either the 289 or the 243 products of E1A is sufficient to immortalize primary rodent cells, but malignant transformation of these cells requires the cooperation of an oncogene (Mymryk, 1996). Therefore, it was initially thought that E1A was an immortalization gene because some transforming oncogenes such as Ras and E1B, which can induce transformation of immortalized rodent cell lines, cooperate with E1A to transform primary rodent cells. The CR2 domain of E1A is essential for the transformation of these cells in culture and the deletion of the CR2 domain abolishes the ability of E1A to cooperate with Ras to transform primary cultures (reviewed in Mymryk, 1996). However, there is no evidence to show that expression of E1A alone is oncogenic and malignant transformation of established cell lines by E1A has not been achieved (Lee et al., 
1999). This is further confirmed by the finding that infection with E1B-deleted adenovirus has a tumoursuppressive effect (Duque et al., 1999). There is no evidence of E1A involvement in human cancers; epidemiological studies have found no linkage between adenovirus infection and occurrence of any human malignancies. Furthermore, adenoviral DNA has not been detected in a wide range of human tumours and attempted immortalization of human cells in culture has been unsuccessful (Branton et al., 1985). More recently it has been shown that E1A has several antioncogenic properties including reversion of malignant transformation, inhibition of metastasis and induction of apoptosis (reviewed in Mymryk, 1996). Expression of the 12S product or coexpression of the $12 \mathrm{~S}$ and $13 \mathrm{~S}$ products is associated with the stabilization of p53 tumour suppressor and this stabilization was thought to be the cause of E1A-dependent apoptosis (Lowe and Ruley, 1993; Chiou et al., 1994). E1A has been shown to transform $\mathrm{p} 53^{-1-}$ mouse embryo fibroblasts (MEFs) but not ${\mathrm{p} 53^{+/+}}$MEFs, probably because apoptosis is induced in p53 proficient cells (Lowe et al., 1994). Theodoro et al. (1995) reported that the $289 \mathrm{R}$ protein is able to induce apoptosis independent of p53, while the presence of p53 was essential for induction of apoptosis by the $243 \mathrm{R}$ protein.

Several reports imply that E1A has tumour-suppressive effects in cancers that overexpress c-erb-B-2-/neu, probably by transcriptional repression of this oncogene. However, tumour suppression by E1A has also been observed in a wide range of human tumour cells that do not overexpress c-erb-B-2/neu (Frisch and Dolter, 1995).

Epidermal growth factor receptor (EGFR) and c-erb$\mathrm{B}-2 /$ neu are members of the tyrosine kinase family (Type 1) of cell surface receptors. The EGFR gene encodes a $170 \mathrm{kDa}$ transmembrane glycoprotein with three functional domains: the EGF-binding extracellular domain, a transmembrane domain and a cytoplasmic tyrosine kinase domain (reviewed in Ishii et al., 1985). Several peptide ligands including epidermal growth factor (EGF), transforming growth factor- $\alpha(\mathrm{TGF}-\alpha)$, vaccinia virus growth factor, amphiregulin and cripto can bind to EGFR (reviewed in $\mathrm{He}$ et al., 1998). The binding of these ligands to EGFR will result in the activation of several signal-transduction pathways that control cell growth and proliferation. Overexpression of EGFR has been associated with increased tumour growth, metastasis and adverse outcome in many epithelial cancers, particularly squamous cell carcinomas of the lung and head and neck (HNSCC) (Salomon et al., 1995; Davies and Chamberlin, 1996).

A number of factors are known to regulate EGFR at the transcriptional level, these include EGFR transcriptional repressors and activators (reviewed in Nishi et al., 2001). Two groups have shown that p53 can transactivate EGFR via binding to EGFR promoter between base pairs -265 and -239 (Ludes-Meyers et al., 1996; Sheikh et al., 1997). The p53 homologue p63 has been shown to repress EGFR expression by preventing Sp1mediated transactivation of EGFR (Nishi et al., 2001). Another cellular target involved in the transcriptional regulation of EGFR expression is the promyelocytic leukaemia gene (PML). PML is a nuclear protein with growth-suppressive properties originally identified in the context of the PML-retinoic acid receptor $\alpha(\mathrm{RAR} \alpha)$ fusion protein of acute promyelocytic leukaemia. PML localizes within distinct nuclear structures called nuclear bodies or PML oncogenic domains (PODs), which are disturbed by the expression of PML-RAR $\alpha$ (Dyck et al., 1994; Weis et al, 1994). The PML genomic locus is approximately $35 \mathrm{~kb}$, which is transcribed as a large number of alternatively spliced transcripts resulting in a variety of PML proteins ranging in molecular weight from 48 to $97 \mathrm{kDa}$ (reviewed in Jensen et al, 2001). Recently, it has been shown that PML might be involved in p53-dependent apoptosis (Fogal et al., 2000) and also in the regulation of gene expression (Wu et al., 2001). Moreover, PML has been shown to interact with the $\mathrm{RB}$ protein in vivo and in vitro. PML$\mathrm{RB}$ interactions result in the inhibition of $\mathrm{RB}$-mediated activation of the glucocorticoid receptor transcription, providing further evidence for the involvement of PML in transcriptional regulation (Alcalay et al., 1998).

It has previously been demonstrated that PML downregulates EGFR expression through interaction with the EGFR promoter (Vallian et al., 1997). The PML-responsive promoter sequences are situated between -150 and -16 of the EGFR gene. The transcription of this region has been shown to be regulated by SP1 and the SP1-dependent activity of the EGFR promoter was shown to be suppressed by PML in a dose-dependent manner (Vallian et al., 1998).

In this study, we have used both plasmid and adenoviral vectors to show efficient induction of apoptosis by E1A in a panel of HNSCC cell lines, but not in normal primary human fibroblasts. Our data demonstrate that E1A induction of apoptosis in these cell lines is independent of the p53 and c-erb-B-2/neu status of the cells and that it occurs via suppression of EGFR expression. This is inferred by the inhibition of E1A-mediated apoptosis in cells constitutively expressing EGFR (under the control of a heterologous promoter), and by the induction of apoptosis as a result of drug-mediated inhibition of EGFR tyrosine kinase activity. E1A induced increase in PML expression, and its altered nuclear localization pattern, together with the ability of PML to suppress EGFR expression, make PML a strong candidate for the E1A-mediated suppression of EGFR expression in HNSCC and lung cancer cell lines.

\section{Results}

E1 $A$ expression suppresses the growth of HN5 head and neck cancer cells

The p53 mutant head and neck cancer cell line HN5 was transfected with either $\mathrm{pE} 1 \mathrm{Aneo}$ or $\mathrm{pSV}_{2}$ neo control vector using calcium phosphate precipitation. Cells were selected with G418 for 4 weeks, after which resistant colonies were scored. Figure 1a shows the mean value of 


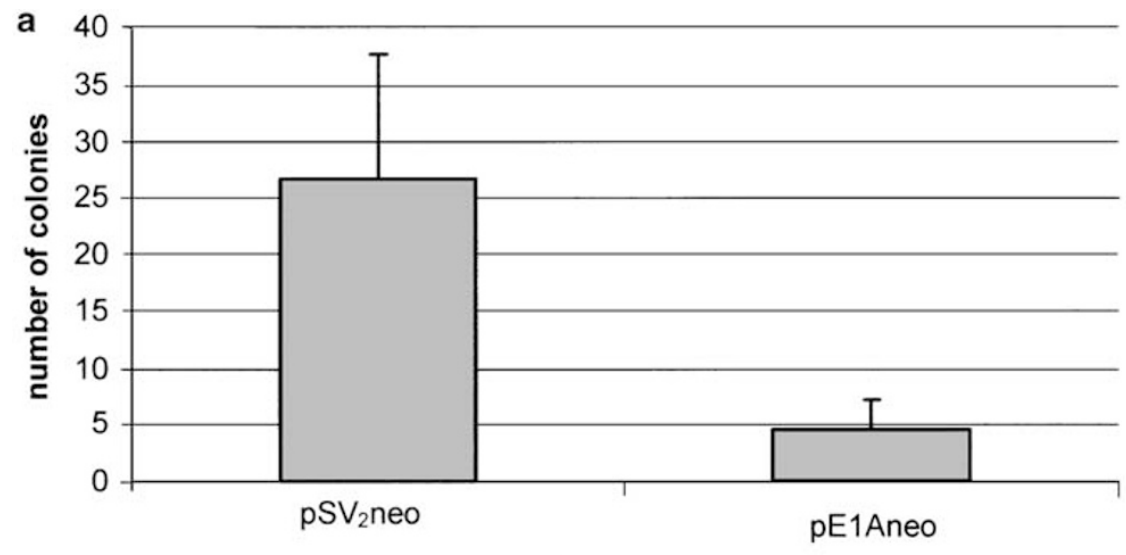

transfected plasmid
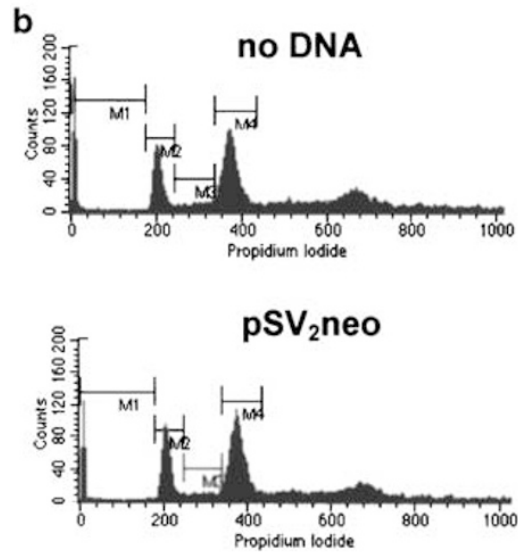

\begin{tabular}{l|lll} 
Marker & no DNA & pSV $_{2}$ neo & pE1Aneo \\
\hline All & 100 & 100 & 100 \\
M1 & 4.7 & 3.7 & 18.5 \\
M2 & 14.9 & 18.2 & 10.5 \\
M3 & 4.6 & 5.4 & 6.2 \\
M4 & 33.6 & 36 & 21.7
\end{tabular}

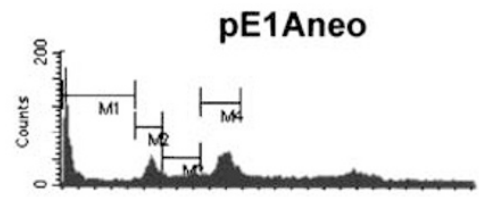

Figure 1 Expression of E1A causes growth inhibition in HN5 cells. (a) E1A expression inhibits colony formation of HN5 cells. Cells were transfected with equimolar quantities of either $\mathrm{pSV}_{2}$ neo or $\mathrm{pE} 1$ Aneo expression vectors; G418-resistant colonies were scored after 3-4 weeks selection. The results represent the average of three independent experiments each performed in triplicate, error bars indicate s.d. (b) Cell cycle analysis of $\mathrm{HN} 5$ cells by FACSCAN $48 \mathrm{~h}$ after transient transfection with $\mathrm{pSV}_{2}$ neo, pE1Aneo or with no DNA. The cell cycle distribution represented as percentages of the total cell population is shown in the table. The markers M1, M2, M3 and M4 indicate the sub-G1, G1, S and G2/M fractions, respectively

three separate experiments performed with HN5 cells (each experiment in triplicate). Significantly lower number of colonies were formed in cultures transfected with the E1A expression vector ( $\mathrm{pE}$ 1Aneo) than in cultures transfected with the control plasmid $\mathrm{pSV}_{2}$ neo.

To investigate whether any of the surviving cells expressed E1A, 14 colonies obtained from several independent transfection experiments with $\mathrm{pE} 1 \mathrm{Aneo}$ were expanded. Western blot analysis showed that none of these colonies expressed E1A suggesting that these colonies had survived because they had lost the expression of E1A while maintaining expression of the selectable marker gene (data not shown).
In order to investigate the effect of E1A expression on the cell cycle, HN5 cells were transiently transfected with $20 \mu \mathrm{g}$ pE1Aneo plasmid and cell cycle distribution of propidium iodide stained cells was analysed by flow cytometry. At $48 \mathrm{~h}$ after transfection, a significant increase in the sub-G1, apoptotic peak, was visible in cells transfected with the E1A (Figure 1b). HN5 cells transfected with $\mathrm{pSV}_{2}$ neo had a cell cycle distribution similar to the nontransfected HN5 cells. At $48 \mathrm{~h} 3.7$ and $4.7 \%$ of the cells, respectively, were in the sub-G1 phase compared with $18.5 \%$ of the pE1Aneo-transfected cells (Figure 1b). 
Infection with Ad-E1A induces apoptosis in a range of head and neck cancer cell lines but not in normal fibroblasts

We next asked whether E1A expression could also induce apoptosis in other HNSCC cell lines. The majority of HNSCC cell lines are extremely difficult to transfect efficiently; therefore, an E1A-expressing adenoviral vector was used to transduce these HNSCC cell lines. Four HNSCC cell lines HN5, HN30, H357 and SCC25, as well as the normal fibroblast cell line 1BR3, were infected with Ad-E1A. As control, we used an adenoviral vector with a mutant, nonfunctional E1A (Ad-mut1E1A). Cells were infected in triplicate with either Ad-E1A or Ad-mut1E1A and cell survival was measured by the MTT assay 24 and $48 \mathrm{~h}$ after infection. At $48 \mathrm{~h}$ after infection with Ad-E1A, a substantial reduction in cell survival was observed in all cancer cell lines (Figure 2a). Survival of HN30 was reduced by more than $70 \%$ with Ad-E1A, while almost $100 \%$ of cells infected with Ad-mut1E1A were still alive. H357 cells were also very efficiently killed $48 \mathrm{~h}$ after infection with Ad-E1A, as the cell survival was reduced to $35 \%$ compared to the $88 \%$ observed in cells infected with Admut1E1A. HN5 cells showed a survival rate of $54 \%$ compared to $86 \%$ in cells infected with Ad-mut1E1A. SCC25 cells were less sensitive to Ad-E1A compared to other cancer cell lines tested and showed only $19 \%$ cell death. SCC25 cells infected with Ad-mut1E1A had a cell survival rate similar to the uninfected cells. Interestingly, 1BR3 normal fibroblasts were resistant to Ad-E1Ainduced cell death. Indeed, expression of E1A-seemed to increase the growth of $1 \mathrm{BR} 3$ cells at both time points (Figure 2a).

To show that the observed differences were not as a result of variations in the transduction efficiencies of the different cell lines, the cells were stained with an E1Aspecific primary antibody. This demonstrated that $100 \%$ of all cells in the HNSCC and normal cell lines expressed E1A 24 h after infection (Figure 2b). To examine cellular a
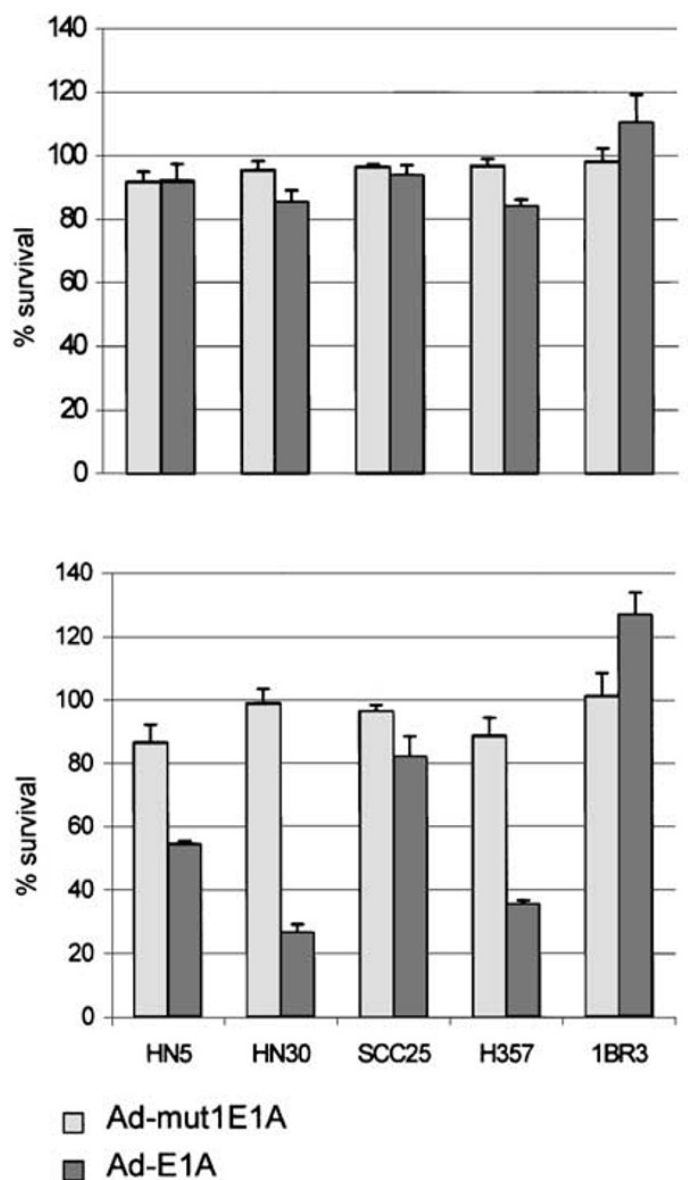

b

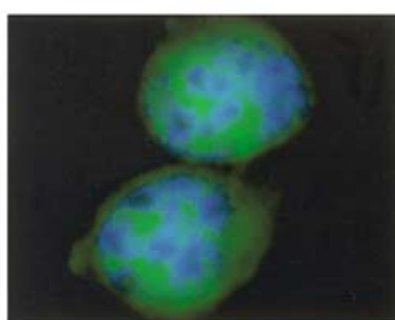

HN5

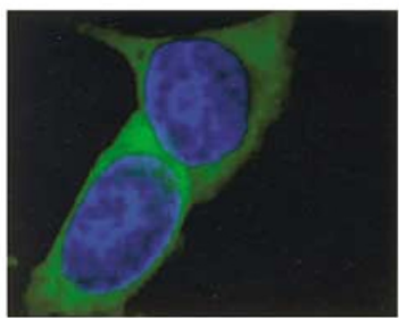

$\operatorname{SCC} 25$

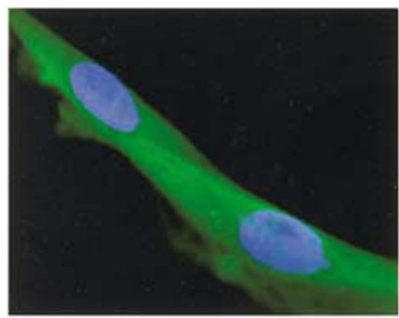

1BR3

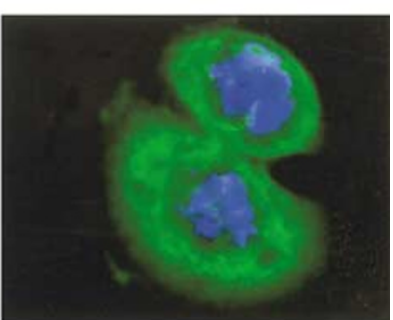

HN30

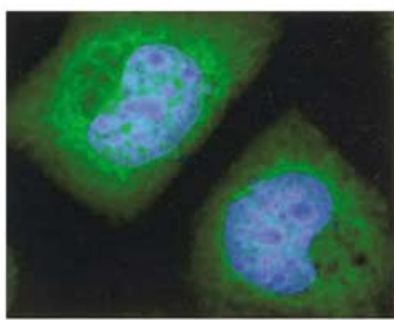

H357

\section{$48 \mathrm{~h}$}

Figure 2 Ad-E1A induces growth inhibition in a range of HNSCC cell lines (a) Cell survival of HN5, HN30, H357 and SCC25 lines was measured by MTT assay at 24 and $48 \mathrm{~h}$ after infection with Ad-E1A or Ad-mut1E1A. Results are shown as percentage of viable cells with respect to noninfected cells. Experiments were performed in triplicate, error bars indicate s.d. (b) Indirect immunofluorescence staining with mouse anti-E1A-specific primary antibody (M58). E1A expression was detected in 100\% of cells at $24 \mathrm{~h}$ after Ad-E1A infection. DAPI staining of DNA shows irregular, condensed blue areas indicative of apoptosis in cancer cells but not in the normal $1 \mathrm{BR} 3$ cell line 
morphology, the cells were counterstained with DAPI that stains cellular DNA. The nuclei of Ad-E1A-infected 1BR3 cells that were resistant to E1A-induced apoptosis, appeared intact and stained homogenously blue with DAPI. However, the nuclei of E1A-infected tumour cells appeared fragmented, indicating the induction of apoptosis. The E1A expression pattern varied in different cell lines; 1BR3 cells showed a mainly cytoplasmic expression pattern. Similarly, in SCC25 cells E1A staining was present mainly in the cytoplasm. Interestingly, these two cell lines were less sensitive to E1A-induced cell death as compared to HN5, HN30 and H357 cells, which showed a more nuclear E1A expression pattern (Figure 2a,b).
E1A suppresses EGFR expression in head and neck cancer cells

E1A has been shown to induce apoptosis in cancer cell lines that overexpress the c-erb-B-2/neu oncogene, by downregulating the expression of c-erb-B-2/neu. Overexpression of c-erb-B-2/neu is uncommon in HNSCC cell lines. However, all four HNSCC cell lines examined had a substantially higher level of EGFR expression than the normal fibroblast cells 1BR3 (Figure 3a). We therefore investigated the effect of E1A on the expression of EGFR in all four HNSCC cell lines. Cells were infected with either Ad-E1A encoding the wild-type E1A protein or two mutant Ad vectors, Ad-mut2E1A and

a

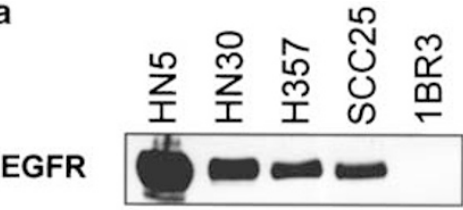

b

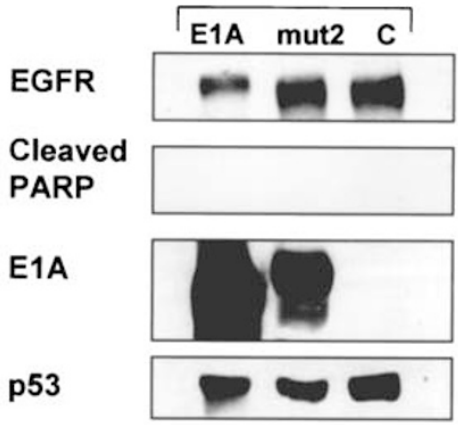

c

$24 \mathrm{~h}$

$48 \mathrm{~h}$

EGFR

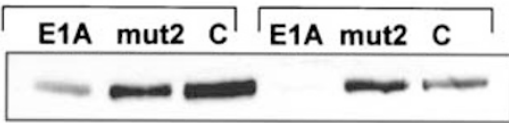

Cleaved

PARP

E1A

p53
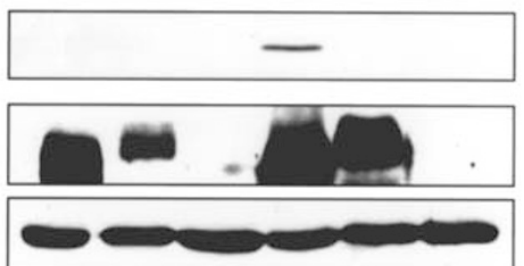

c-Cbl

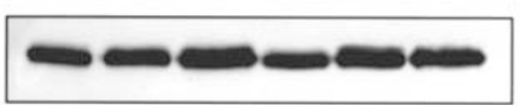

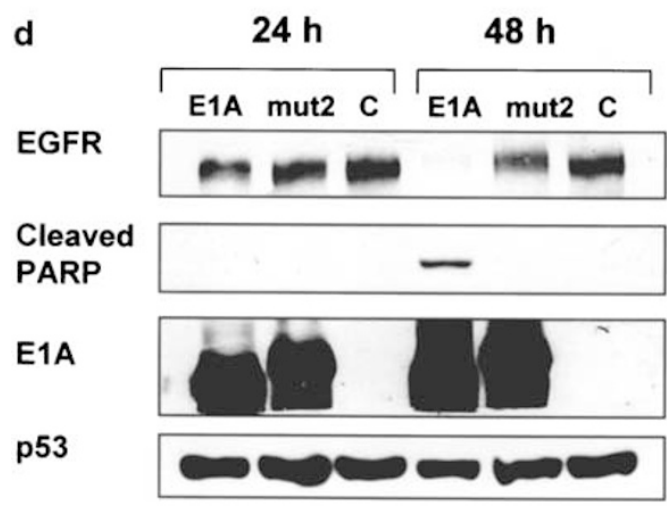
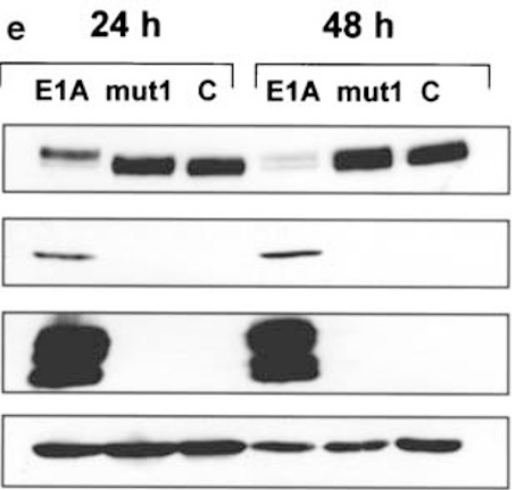

PML

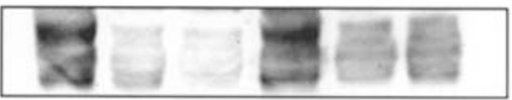

Figure 3 Expression of E1A induces downregulation of EGFR expression in HNSCC cell lines. (a) Analysis of EGFR expression in HNSCC cells by Western blot using F4 mouse primary antibody against EGFR. Western blot analysis of expression of EGFR, cleaved PARP, c-Cb1, E1A, p53 and PML proteins using F4, G734A, c-15, M58, DO7 and PML3573 primary antibodies, respectively. HN30 (b), HN5 (c), SCC25 (d) and H357 (e) cells were infected with Ad-E1A (E1A) and as a control with Ad-mut2E1A (mut2) or Admut1E1A (mutl) vectors. Cells were lysed 24 and $48 \mathrm{~h}$ after infection, $50 \mu \mathrm{g}$ of total protein from each sample was separated by SDSPAGE, transferred to nitrocellulose and hybridized to different antibodies as described in the Materials and method section 
Ad-mut1E1A. Ad-mut2E1A encodes a mutated form of E1A that is nonfunctional, but still detectable with the M58 anti-E1A antibody. Ad-mut1E1A encodes a single nucleotide deletion in E1A making the E1A protein both nonfunctional and nondetectable by M58 antibody. At $24 \mathrm{~h}$ after infection of HN30 cells with AdE1A, there was a clear reduction in EGFR levels compared to cells infected with Ad-mut2E1A (Figure $3 \mathrm{~b}$ ). Over $70 \%$ of HN30 had died $48 \mathrm{~h}$ after Ad-E1A infection; therefore, the protein expression level for this time point could not be analysed. Expression of E1A for $48 \mathrm{~h}$ resulted in an almost complete suppression of EGFR expression in SCC25, HN5 and H357 cells compared to cells infected with adenoviral vectors expressing mutant E1A (Figure 3b-e). To confirm that reduction in the EGFR levels was not because of a general decrease in cellular protein levels caused by apoptosis, the blots were stripped and reprobed with the DO-7 anti-p53 antibody. All the HNSCC cell lines containing high levels of p53, SCC25, HN5 and H357 express stabilized mutant p53 (Sartor et al., 1999), while HN30 cells express high levels of wild-type p53 (Yeudall et al., 1997). There was no association between E1A expression and alterations in the p53 levels in the different samples (Figure 3b-e).

To examine if the EGFR downregulation and cell killing induced by Ad-E1A-activated a known apoptotic pathway such as caspase 3, E1A-infected cells and controls were analysed for the cleavage of PARP. Western blot analysis using an antibody that specifically detects the cleaved $85 \mathrm{kDa}$ PARP fragment showed the presence of this protein in HN15 and SCC25 cells $48 \mathrm{~h}$ after infection with Ad-E1A (Figure 3c, d). HN5 and SCC25 cells infected with Admut2E1A did not express the cleaved PARP protein. In $\mathrm{H} 357$ cells, the $85 \mathrm{kDa}$ cleaved PARP protein was observed at both 24 and $48 \mathrm{~h}$ after infection with AdE1A, but absent in the Ad-mut1E1A infected cells (Figure 3e). There was a clear association between downregulation of EGFR and the presence of cleaved PARP. These data suggest that a caspase-dependent pathway is involved in the E1A- induced apoptosis. Therefore, we could not detect cleaved PARP in HN30 cells. This could be because of the rapid induction of apoptosis and early loss of apoptotic cells from the infected culture.

It has been shown that EGFR expression is downregulated by $\mathrm{c}-\mathrm{Cb} 1$, which plays a role in the degradation of EGFR via clathrin-mediated endocytosis. c-Cb1 ubiquitinates EGFR, which targets the protein for degradation by either proteasomes or lysosomes (de Melker et al., 2001). We speculated that E1A expression might cause activation of $\mathrm{c}-\mathrm{Cb} 1$, which could in turn result in EGFR degradation. To test this hypothesis Western blots were stripped and reprobed with c-15 antibody specific to c-Cb1 (Santa Cruz Biotechnology). Comparable levels of the $120 \mathrm{kDa}$ c-Cb1 protein were detected by Western blotting in Ad-E1A-as well as in Ad-mut2E1A-infected or control HN5 cells, indicating that E1A does not activate the expression of $\mathrm{c}-\mathrm{Cb} 1$ (Figure 3d).
Table 1 Inhibition of cell survival by EGFR tyrosine kinase inhibitor AG1478

\begin{tabular}{lll}
\hline Cell line & $0 \mu \mathrm{M} A G 1478$ & $6.25 \mu \mathrm{M} A G 1478$ \\
\hline HN5 & $100 \pm 1.9$ & $50.8 \pm 7.9$ \\
HN30 & $100 \pm 6.2$ & $55.4 \pm 18.8$ \\
SCC25 & $100 \pm 3.5$ & $41.8 \pm 3.8$ \\
H357 & $100+2.7$ & $34.2 \pm 3.7$ \\
H1299 & $100+2.8$ & $42.3 \pm 0.7$ \\
\hline
\end{tabular}

MTT assay showing reduction in survival of HNSCC and H1299 cell lines treated for $48 \mathrm{~h}$ with EGFR tyrosine kinase inhibitor AG1478. Results are shown as percentage of surviving cells with respect to nontreated cells. Experiments were performed in triplicate, the mean \pm s.d. is indicated

To investigate whether EGFR activity was important for the growth of HNSCC cells, EGFR tyrosine kinase inhibitor, AG1478 (Fry et al., 1994) purchased from Calbiochem, was used to examine its effect on the HNSCC and H1299 cell lines. Cells were treated with several concentrations of AG1478 ranging from 100 to $6.25 \mu \mathrm{M}$. Substantial reductions in cell survival were detected by the MTT assay in each of the five cancer celllines treated with $6.25 \mu \mathrm{M}$ AG1478. Therefore, the activity of EGFR is important for the survival of these cells and the suppression of its function, either by AG1478 or E1A, results in the death of EGFR overexpressing cells (Table 1).

\section{E1 $A$ alters the pattern of PML expression in head and neck cancer cells}

It has previously been demonstrated that PML downregulates EGFR expression through interaction with the EGFR promoter. The PML-responsive promoter sequences are situated between -150 and -16 of the EGFR gene (Vallian et al., 1998). This region overlaps with the EGFR promoter region responsive to E1A (Prudenziati et al., 2000). We therefore sought to determine the effect of E1A on PML expression. HNSCC cell lines HN5, HN30, SCC25 and H357 were infected with Ad-E1A and Ad-mut1E1A. The PML expression pattern was examined 24 and $48 \mathrm{~h}$ after infection. In Ad-mut1E1A-infected cells PML expression was detected as the characteristic PML bodies mainly composed of round regular dots (Figure 4a). This was similar to the pattern observed in noninfected cells (data not shown). A considerable change in PML expression patterns was observed in all cell lines infected with Ad-E1A (Figure 4a). In these cells, PML expression became disturbed and irregular compared to the pattern present in noninfected cells or cells infected with Ad-mut1E1A. The effect of E1A on the level of PML was also examined by Western blot analysis. Infection of H357 cells with Ad-E1A resulted in increased PML protein levels and in particular the increased presence of $68 \mathrm{kDa}$ isoform of this protein known as PML IV (Figure 3e). The E1A-induced increase in the total cellular levels of PML may be directly or indirectly responsible for the altered nuclear distribution of PODs in these cells. 
Ad-mut1E1A

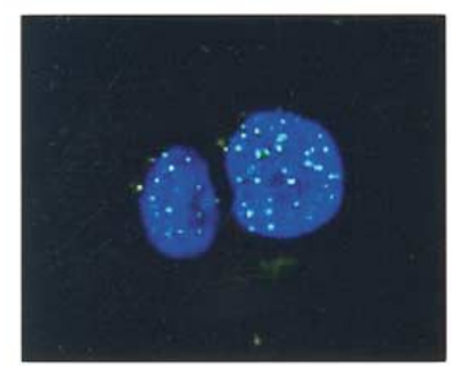

N30

$48 \mathrm{~h}$
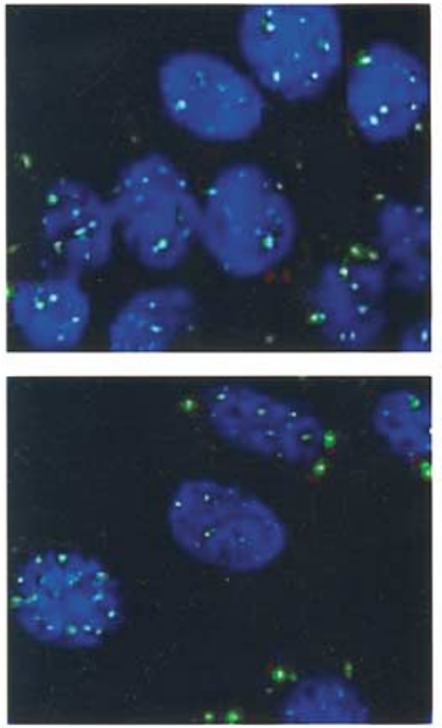

$\operatorname{SCC} 25$

$24 \mathrm{~h}$

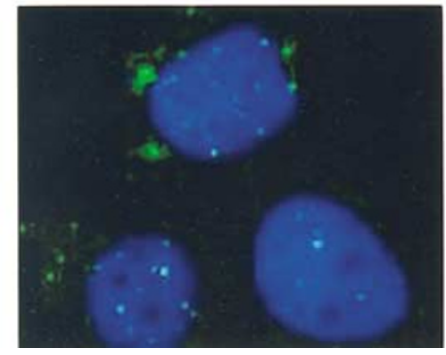

Ad-E1A
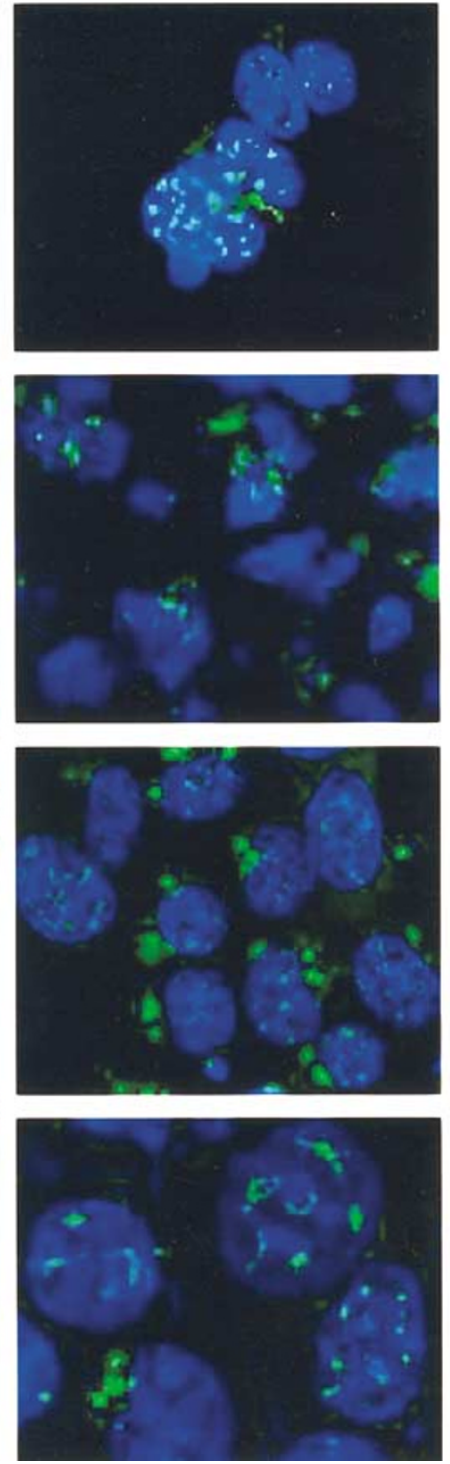

Ad-mut1E1A

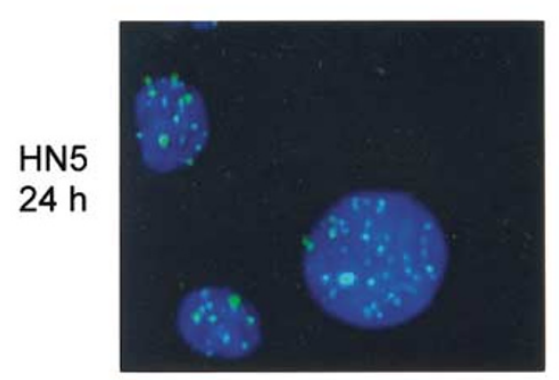

HN5

$48 \mathrm{~h}$
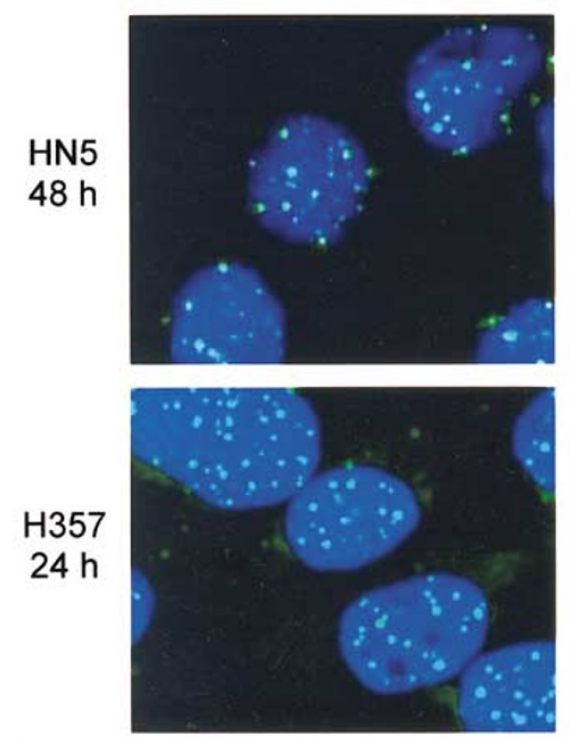

H357

$48 \mathrm{~h}$

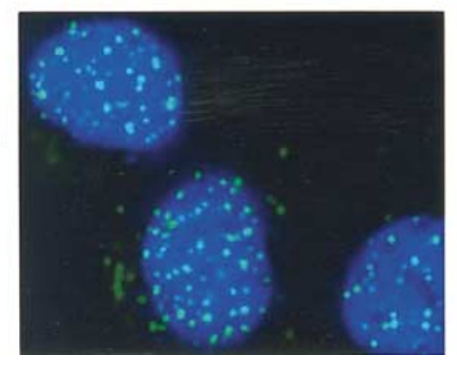

Ad-E1A
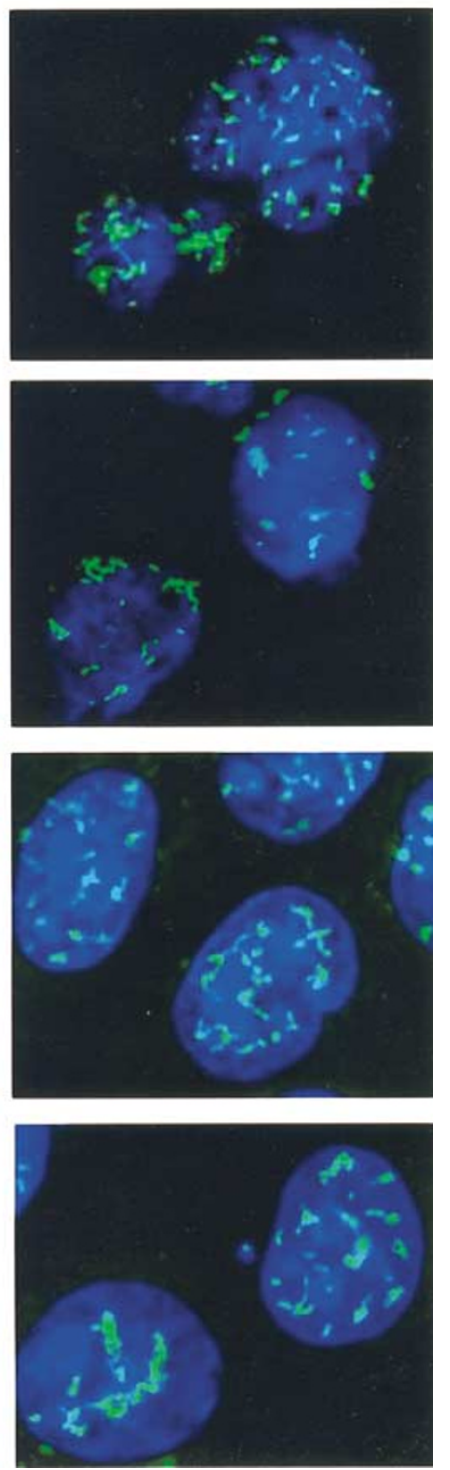

Figure 4 PML expression detected by indirect immunofluorescence. Indicated cell lines were grown on slide chambers. At 24 and $48 \mathrm{~h}$ after Ad-E1A and Ad-mut1E1A infection, cells were fixed and stained with rabbit anti-PML antibody and secondary FIT-C conjugated antibody. Slides were mounted in a solution containing DAPI to detect the nuclear morphology. PML nuclear bodies (PODs) are detected as bright green spots/patches 


\section{Exogenous EGFR expression protects cancer cells from} E1A-induced apoptosis

In order to investigate whether EGFR downregulation was the cause or consequence of E1A-induced apoptosis, we used H1299 lung cancer cell line that expresses moderate levels of EGFR. Ad-E1A infection induced substantial apoptosis in these cells (Figure 5a, b). E1Ainduced apoptosis in H1299 cells was associated with a significant downregulation of EGFR (Figure 6a). In addition, contrary to HNSCC cells H1299 cells could be

a

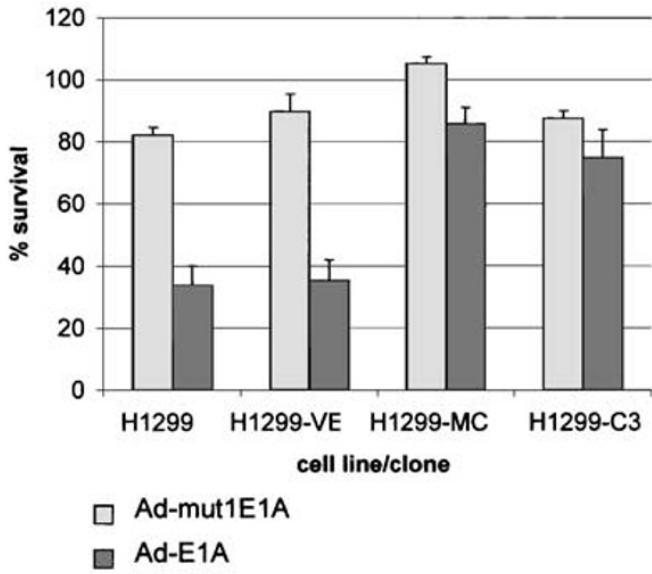

b

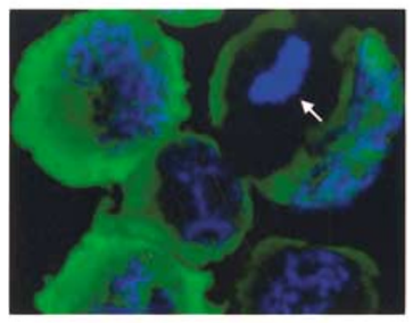

H1299

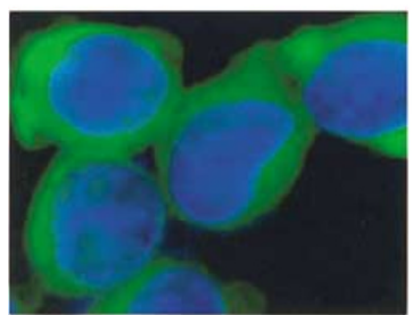

H1299-MC

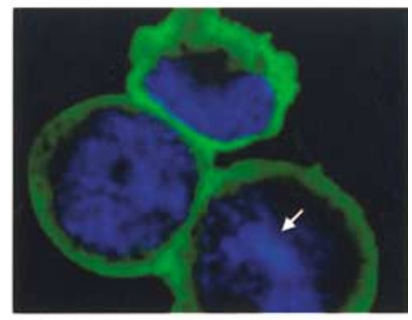

H1299-VE

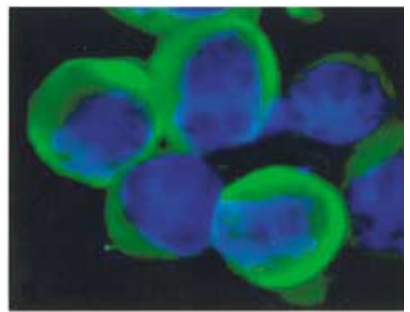

H1299-C3
Figure 5 Exogenous EGFR expression protects H1299 cells from killing by Ad-E1A. H1299 cells were infected with EGFR pBabepuro retroviral vector as well as with empty control vector. After selection in puromycin H1299 empty vector (pBabepuro) mixed population (H1299-VE), H1299 pBabepuro-EGFR clone (H1299-C3) and H1299 pBabepuro-EGFR mixed population (H1299-MC) were expanded and infected with either Ad-E1A or Ad-mut1E1A. (a) MTT assays showing cell viability $48 \mathrm{~h}$ after infection with Ad-E1A and Ad-mut1E1A. Experiments were performed in triplicate, error bars indicate s.d. (b) Indirect immunofluorescence staining using mouse anti-E1A clone M58 shows E1A expression in all H1299, H1299-VE, H1299-C3 and H1 299 cells $48 \mathrm{~h}$ after Ad-E1A infection readily transfected or infected with retroviral vectors thus making them suitable for the study of the effect of maintaining the EGFR expression at a high level. Therefore, these cells were infected with a pBabepuro retroviral vector containing EGFR or the control vector. Several clones were expanded after selection in puromycin and checked for the expression of exogenous EGFR expression. The selected colonies expressed exogenous EGFR, detectable as a $170 \mathrm{kDa}$ band (results not shown). The parental H1299 cells, control vector transduced cells (H1 299-VE), a high-level exogenous EGFR expressing clone (H1299-C3) and the mixed population of exogenous EGFR expressing cells (H1299-MC) were infected with Ad-E1A or Ad-mut1E1A. Cell viability was measured by MTT assay at $48 \mathrm{~h}$ postinfeetion. The H1299-MC and H1299-C3, which expressed exogenous EGFR, were substantially more resistant to E1A-induced apoptosis than either the parental or the control vector-infected cells. The H1299MC and H1299-C3 cells had a viability of 85.7 \pm 5.3 and $74.7 \pm 2.8 \%$ respectively, compared to H1299 cells and $\mathrm{H} 1299-\mathrm{VE}$ in which viability was reduced to $33.6 \pm 6.4$ and $35.2 \pm 6.9 \% 48 \mathrm{~h}$ after Ad-E1A infection (Figure 5a).

Indirect immunofluorescence staining, using the E1A antibody, indicated that essentially all the cells infected with Ad-E1A expressed the E1A protein (Figure 5b). DAPI staining showed the presence of apoptotic nuclei in the Ad-E1A-infected H1299 cells and H1299-VE, but not in cells expressing a high level of exogenous EGFR (H1299-MC and H1299-C3) (Figure 5b).

We next investigated the effect of E1A on the levels of exogenous EGFR expression. As shown in Figure 6a, the levels of endogenous EGFR expression was significantly reduced in $\mathrm{H} 1299$ and H1299-VE cells $48 \mathrm{~h}$ after infection with Ad-E1A compared to cells infected with Ad-mut1E1A. However, there was no downregulation of EGFR expression in H1299-MC and H1299-C3 that expressed exogenous EGFR (Figure 6a). To confirm that the observed downregulation of EGFR in Ad-E1A-infected cells was not because of loading differences, the blots were stripped and reprobed to an antibody against microtubuli associated protein (MAP) that detected comparable level of protein in all cell lines. These results indicate that EGFR expressed from a heterologous promoter is not susceptible to E1A-mediated downregulation and protects cells from E1A-mediated apoptosis.

We also examined whether E1A expression affected the PML distribution pattern in H1299 cells that expressed exogenous EGFR. In H1299 and H1299-VE cells, which only express endogenous EGFR, infection with Ad-E1A resulted in both increased levels and altered distribution of PML compared to cells that were infected with Ad-mut1E1A (Figure 6b). In the Ad-E1Ainfected H1299-MC cells, expressing exogenous EGFR, the changes in PML expression and distribution were less pronounced than in H1299 cells expressing only the endogenous EGFR. The mechanism by which EGFR expression reduces the effect of E1A on PML distribution remains unclear, but is not without precedent (Tian et al., 1999). 
b

a
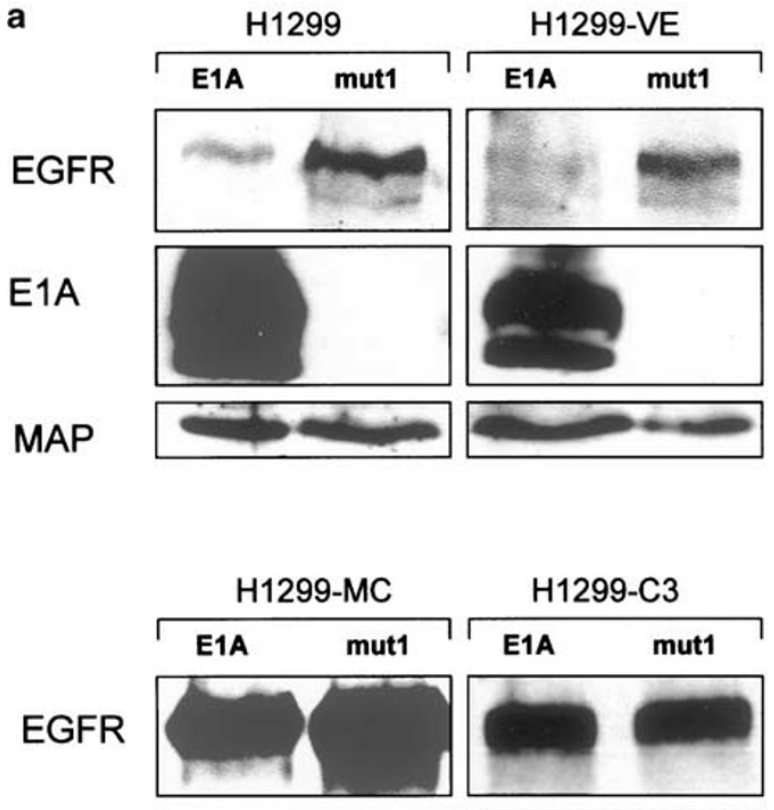

E1A

MAP

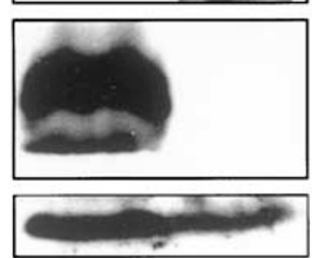

H1299-C3
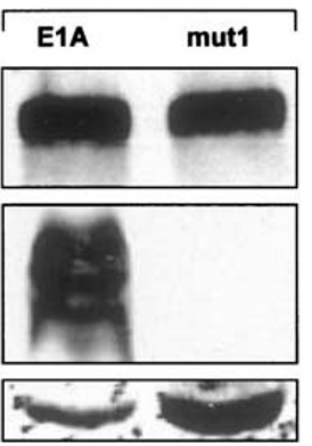
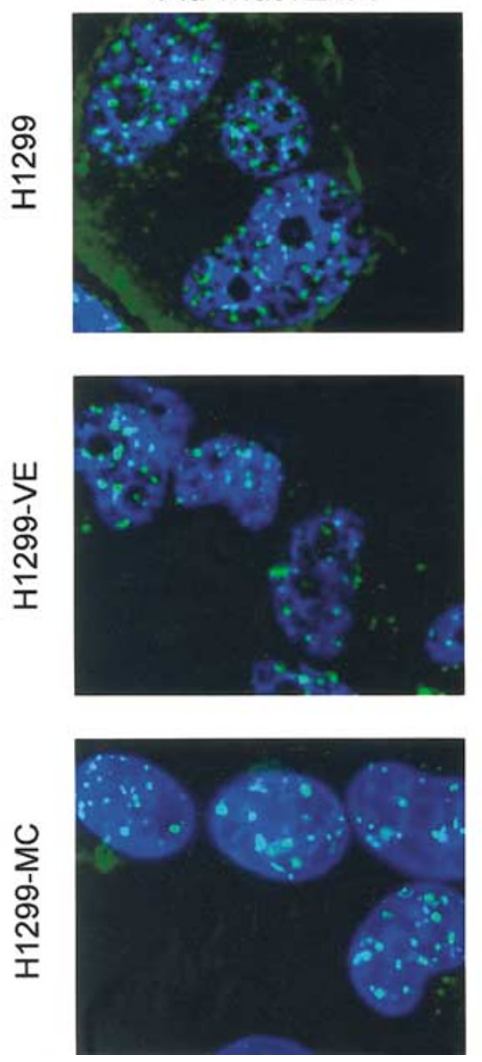

Figure 6 E1A expression downregulates endogenous but not exogenous EGFR in H1299 cells. (a) Expression of EGFR, E1A and MAP was analysed by Western blotting after infection of H1299, H1299-VE, H1299-MC and H1299-C3 48 h after infection with AdE1A (E1A) and Ad-mut1E1A (mut1). (b) PML expression was detected by indirect immunofluorescence using the rabbit anti-PML antibody $24 \mathrm{~h}$ after Ad-E1A and Ad-mut1E1A infection of H1299, H1299-VE and H1299-MC

\section{Discussion}

Expression of EGFR has shown to be important in the pathogenesis of most epithelial malignancies, $45 \%$ of nonsmall cell lung cancer (NSCLC) (Rusch et al., 1993) and more than $50 \%$ of head and neck cancers overexpress EGFR (Irish and Bernstein, 1993). Activation of the EGFR pathway is involved in several aspects of cellular carcinogenesis including activation of the Ras/ mitogen-activated protein kinase cascade and induction of cyclin Dl. Additionally, EGFR is implicated in the control of tumour cell apoptosis, angiogenesis and metastasis (Woodburn, 1999; Averbuch, 2002).

In the present study, we have demonstrated that E1A expression induced cell death in a range of head and neck squamous carcinoma cell lines that overexpress EGFR.

Lowe et al. (1994) have shown E1A induced death of cells that express wild-type $\mathrm{p} 53$ but not cells with deleted or mutated $\mathrm{p} 53$, suggesting the need for the presence of wild-type $\mathrm{p} 53$. E1A expression was shown to result in the accumulation of $\mathrm{p} 53$ by prolonging the protein halflife of p53 (Lowe and Ruley, 1993). This stabilization of p53 by E1A was suggested to be the result of the activation of p19/ARF protein and inhibition of MDM2, the product of which interacts with and promotes the degradation of p53 (de Stanchina et al., 1998). It has also been shown that E1A binds and inhibits the transcriptional co-adaptor p300 (Stein et al., 1990). Inhibition of p300 by E1A prevents the transcriptional activation of MDM2, and therefore MDM2 mediated degradation of $\mathrm{p} 53$. In the present study, we show that E1A-induced cell killing is independent of the p53 status, as it occurred in cells with wild-type (HN30), mutated (HN5, SCC25, H357) or deleted (H1299) p53. However, HN30 cells, which express high levels of wildtype p53, were significantly more sensitive to E1Ainduced killing than the other cancer cell lines examined. This result suggests that although p53 may not be required for E1A to induce cell death, its presence could enhance the E1A-induced apoptotic process. Furthermore, the normal (passages 5-8) human fibroblasts 1BR3, which contains a wild-type p53, was substantially more resistant to E1A-induced cell death than all the cancer cell lines. The inability of E1A to induce apoptosis in normal 1BR3 cells suggests that E1A may have some tumour cell specificity for its apoptotic function. Interestingly, E1A expression in 1BR3 cells was predominantly cytoplasmic, while in the cancer cell lines E1A was mainly localized to the perinuclear/ nuclear compartment suggesting that the cellular sublocalization may be important for the induction of 
apoptosis by E1A. FACS analysis and Western blotting with antibodies against the apoptosis-associated cleaved PARP showed that E1A-induced death of HNSCC cells was because of apoptosis.

E1A expression has been shown to inhibit cell proliferation of lung, ovarian and breast cancer cells overexpressing c-erb-B-2/neu, a member of the EGFR family (Yu et al., 1995; Chang et al., 1996, 1997). c-erb$\mathrm{B}-2 /$ neu overexpression is uncommon in head and neck cancers while EGFR overexpression was detected in each of the four HNSCC cell lines examined (Figure 3a). Infection with adenovirus expressing a functional E1A, but not with an adenovirus expressing a mutant E1A, resulted in a significant downregulation of endogenous EGFR expression in each of the four HNSCC and one lung cancer cell lines examined.

To investigate whether E1A downregulation of EGFR occurred indirectly through activation or suppression of genes that are involved in the regulation of EGFR expression we analysed the expression of $\mathrm{c}-\mathrm{Cb} 1$ proto-oncoprotein. Mammalian c-Cb1 and its homologues in Caenorhabditis elegans and Drosophila are evolutionarily conserved negative regulators of EGFR. Wild-type c-Cb1 enhances ligand-dependent EGFR ubiquitination, downregulation, accumulation in intracellular vesicles and degradation (Lill et al., 2000). We studied the expression of c-Cb1 in different cell lines and examined the effect of E1A on its protein level. No correlation was found between the levels of $\mathrm{c}-\mathrm{Cb} 1$ and EGFR expression in the panel of cell lines studied (manuscript in preparation). In addition, E1A seemed to have no effect on the levels of $\mathrm{c}-\mathrm{Cb} 1$ protein in the cell lines tested, suggesting that downregulation of EGFR was not because of increased levels of $\mathrm{c}-\mathrm{Cb} 1$.

A number of genes are known to suppress EGFR transcriptional, including the p53 homologue p63, which has been shown to repress EGFR expression by interacting with $\mathrm{Sp} 1$, thus preventing Sp1-mediated activation of EGFR transcription (Nishi et al., 2001). PML has also been shown to suppress EGFR expression by binding to EGFR promoter. The PML-responsive promoter sequences appear to be located between -150 and -16 of the EGFR gene promoter. This region is rich in Sp1-binding sites, suggested to interact with PML to downregulate EGFR promoter activity (Vallian et al., 1998). On the other hand, transfection of EGFR overexpressing glioblastoma cells with an EGFR antisense-cDNA expression vector has been shown to result in the induction of $\mathrm{Gl}$ arrest and upregulation of PML and p53 expression, while levels of pRB, p16 ink4a and $\mathrm{p} 21^{\text {wafl }}$ were not altered (Tian et al., 1999). Therefore, while EGFR itself is subject to PML-mediated suppression of transcription, it appears to be able to downregulate expression of PML and $\mathrm{p} 53$.

Prudenziati et al. (2000) have recently reported E1Amediated suppression of the EGFR promoter activity. They show that cotransfection of HeLa cells with E1A and EGFR-CAT reporter plasmid results in the downregulation of CAT activity. However, E1A-induced apoptosis by downregulation of the endogenous EGFR in EGFR overexpressing cancer cells has not been previously shown. The region between -150 and -76 of the EGFR promoter was shown to be required for downregulation by E1A. This region overlaps with the EGFR promoter region responsive to PML. We therefore investigated the effect of E1A on the level of PML and the distribution of PODs in four HNSCC cancer cell lines. Immunofluoresence staining of PML revealed its altered expression pattern in cells infected with Ad-E1A but not those infected with Ad-mut1E1A. PML expression was found to convert from the nuclear dot pattern into a more intense, patch-like pattern. Similar redistribution of PML expression from the nuclear dot pattern to the patch-like or a fine granulated homogeneous staining pattern has been reported in cells treated with the antisense-EGFR (Tian et al., 1999). Although we have no direct evidence for the involvement of PML in the downregulation of EGFR, the presented data do suggest a possible link between E1Ainduced alteration of PODs and EGFR downregulation resulting in the induction of apoptosis in these cancer cell lines. PML colocalizes with proteins including SP100, NDp55, PIC 1, Int-6 and SUMO in the POD. PML also plays a role in the replication and host cell infection by a number of different viruses (reviewed in Jensen et al., 2001). One hypothesis put forth is that the nuclear bodies or POD may represent storage sites for certain matrix proteins that are readily accessible throughout the chromatin in response to stress or other effectors that induce global nuclear changes. Thus, PML may act as a 'matchmaker' to recruit or sequester other proteins in or out of the POD (Maul et al., 1995). The redistribution of PML from dotted structures to the patched-like staining pattern in E1A expressing cells may represent a 'global' rearrangement of nuclear proteins. Altered patterns of PODs are also observed with PML/RAR- $\alpha$ that has an impaired transcriptional suppression function. However, fusion of PML to RAR$\alpha$ removes some sequences important for PML function. Although the nonphosphorylated form of RB interacts with both PML and with PML/RAR- $\alpha$, only PML but not PML/RAR- $\alpha$ has an inhibitory effect on $R B$ transactivation, suggesting that an interaction between PML and pRB might be important in the regulation of cell differentiation and proliferation. PML/RAR- $\alpha$ could antagonize this effect and thereby contribute to a deregulation of cellular proliferation. In addition, the PML IV isoform has been shown to repress transcription of genes by interacting with histone deacetylase (HDAC) (Wu et al., 2001). In contrast, PML/RAR- $\alpha$ interacts poorly with HDAC suggesting that the transcriptional-silencing function of PML might be disturbed by the expression of PML-RAR- $\alpha$ that lacks the C-terminal of PML (Saha et al., 1998).

In addition to redistribution of PODs, infection of HNSCC cells with Ad-E1A but not Ad-mutE1A resulted in increased levels of PML protein, particularly, the $68 \mathrm{kDa}$ PML IV isoform. This observation shows an effect by Ad-E1A on PML expression. Increased PML levels may be the cause of the detected reorganization of PODs induced by E1A expression. Interestingly, PML IV isoform has also been shown to interact with p53 and 
recruit $\mathrm{p} 53$ into PML nuclear bodies resulting in reduced cell survival (Fogal et al., 2000). PML IV has also been shown to interact with nonphosphorylated active RB protein (Alcalay et al., 1998). The presented data support the notion that PML levels and distribution patterns may play important roles in modulating transcription, resulting in the activation of growthsuppressing genes or suppression of survival signals such as those provided by EGFR. Further studies are required to determine whether there is a direct link between the E1A effects on PML-mediated downregulation of EGFR and the induction of apoptosis.

To investigate whether transcriptional downregulation of EGFR by E1A was the direct cause of apoptosis in the cell lines studied, we expressed a full-length EGFR cDNA from a viral LTR promoter. We infected HNSCCs and H1299 cells with the retroviral vector pBabepuro-EGFR and tried to establish clones that stably expressed exogenous EGFR. We were unable to obtain clones from HN30 and $\mathrm{H} 357$ cell lines because of the very low transfection and retroviral infection efficiency of keratinocytes as compared to the very efficient transduction with adenoviral vectors. However, we obtained pBabepuro-EGFR clones from two cell lines, HN5 and H1299, infected with this retroviral vector. HN5 cells were unsuitable to study the effects of exogenous EGFR because they have over a 100-fold gene amplification/overexpression of EGFR that could mask any effect induced by exogenous EGFR. We therefore decided to use H1299 cells expressing moderate levels of EGFR. E1A expression did not induce cell death in the H1299 expressing exogenous EGFR, while E1A did significantly reduce the survival of the parental H1299 and H1299 cells transduced with the control vector. E1A-induced changes in PML distribution were less obvious in the cells expressing exogenous EGFR. These results suggest that downregulation of endogenous EGFR protein by E1A is likely to be at the transcriptional level. This may be either by E1A itself directly suppressing the EGFR promoter or its indirect effects via other factors such as PML.

In summary, this study demonstrates that E1A is able to effectively induce apoptosis in both head and neck and lung cancer cell lines. The induction of apoptosis by E1A is mediated through downregulation of EGFR, and cancer cells that overexpress EGFR are significantly more sensitive to E1A-induced apoptosis than normal cells. These results could aid the development of effective and possibly tumour-specific strategies for the treatment of head and neck cancers, the majority of which overexpresses EGFR.

\section{Materials and methods}

\section{Cell culture}

HNSCC cell lines HN5, HN30, SCC25, nonsmall lung cancer cell line H1299, 293A adenoviral packaging cells and PA317 retroviral packaging cells were cultured in Dulbecco's modified eagle medium (DMEM) supplemented with $10 \%$ FCS, $2.5 \mu \mathrm{g} /$ $\mathrm{ml}$ streptomycin, $5 \mu \mathrm{g} / \mathrm{ml}$ penicillin and $1 \mathrm{~mm}$ sodium pyruvate, all purchased from Sigma. 1BR3 normal human fibroblasts (passages 5-8) were grown in DMEM containing the indicated supplements and 15\% FCS. HNSCC cell line H357 was cultured in Nut-mix medium (Gibco) including 5\% FCS. Cultures were incubated at $37^{\circ} \mathrm{C}$ and $5 \% \mathrm{CO}_{2}$.

\section{Plasmids and DNA transfection}

Plasmids used for transfection were: $\mathrm{pSV}_{2}$ neo, $\mathrm{pE} 1 \mathrm{Aneo}$ (provided by Dr Mien-Chie Hung, Department of Molecular and Cellular Oncology, MD Anderson Cancer Centre, USA), pBabepuro and pBabepuro-EGFR (provided by Dr Paolo DiFiore, Department of Experimental Oncology, Instituto Europeo di Oncologia, Milan, Italy). Cells were plated 1 day before transfection in 100-mm-diameter (or $60 \mathrm{~mm}$-diameter) dishes. For each dish, $8 \mu \mathrm{g}$ ( $3 \mu \mathrm{g}$ for $60 \mathrm{~mm}$ dishes) DNA was used for stable transfection and $20 \mu \mathrm{g}$ DNA ( $8 \mu \mathrm{g}$ for $60-\mathrm{mm}-$ diameter dishes) for transient transfection. DNA was resuspended in $450 \mu \mathrm{l}$ sterile $\mathrm{dH}_{2} \mathrm{O}$ and $50 \mu \mathrm{l}$ of $2.5 \mathrm{M} \mathrm{CaCl}_{2}$. To this mixture $500 \mu$ l of $2 \times$ BES solution ( $50 \mathrm{~mm}$ BES, $280 \mathrm{~mm} \mathrm{NaCl}$, $1.5 \mathrm{~mm} \mathrm{Na} \mathrm{HPO}_{4}, \mathrm{pH}$ 6.96) was added dropwise while vortexing slowly. The mixture was incubated for $15 \mathrm{~min}$ at room temperature and was added dropwise to the cells. After 16-20 $\mathrm{h}$ incubation the medium was removed, the plates were washed once with DMEM and fresh complete medium was added to the cells. Stable clones were selected in a medium containing $500 \mu \mathrm{g} / \mathrm{ml} \mathrm{G} 418$ sulphate (Calbiochem) for 3-4 weeks.

For the generation of EGFR pBabepuro clones, PA317 mouse fibroblast packaging cells were transfected with EGFR pBabepuro expressing wild-type human EGFR cDNA or empty vector. Transfected cultures were grown in complete medium supplemented with $2 \mu \mathrm{g} / \mathrm{ml}$ puromycin (Sigma) for 2 weeks. Resistant colonies were picked, expanded and examined for EGFR expression by Western blot analysis as described below. The supernatant of a clone with the highest level of EGFR expression was used to infect recipient cell lines. Control cells were infected with supernatant containing pBabepuro empty vector.

\section{Colony formation assays}

$\mathrm{HN} 5$ cells were transfected with $8 \mu \mathrm{g} / 100 \mathrm{~mm}$ dish of $\mathrm{pSV}_{2}$ neo or $\mathrm{pE} 1 \mathrm{Aneo}$. The transfection efficiency was normalized using pCH110 vector encoding the lac-Z gene. At $16-20 \mathrm{~h}$ after transfection, the medium was removed, the plates were washed once with DMEM and fresh complete medium was added to the cells. After 3-4 weeks of selection in medium containing $500 \mu \mathrm{g} / \mathrm{ml} \mathrm{G} 418$ sulphate, resistant colonies were counted.

\section{Western blot analysis}

Cells were washed once in cold phosphate-buffered saline (PBS) and lysed in Laemmli Sample buffer $(62.5 \mathrm{~mm}$ Tris-Cl pH 6.7, $100 \mathrm{~mm} \beta$-mercaptoethanol, $2 \%$ SDS, $1 \mu \mathrm{g} / \mathrm{ml}$ aprotinin, $100 \mu \mathrm{g} / \mathrm{ml}$ phenylmethylsulphoxide). The lysate was passed through a $25 \mathrm{G}$ needle and boiled for $4 \mathrm{~min}$. Lysates were resolved by gel electrophoresis for $1.5-2 \mathrm{~h}$ at $100 \mathrm{~V}$ on 6 $8 \%$ SDS-polyacrylamide gels. Western Blotting was performed as previously described (Sartor et al., 1999). The antibodies used for Western blot analysis were: mouse antiE1A clone M73 (Oncogene) in a 1:1000 dilution for detection of E1A expressed from the pE1Aneo vector, mouse anti-E1A clone M58 (Pharmingen) in a 1:500 dilution for detection of adenoviral E1A, mouse anti-EGFR clone F4 (gift from Prof William Gullick, Department of Biosciences, University of Kent at Canterbury, UK) in a dilution of $1: 1000$, rabbit 
anti-PARP p85 fragment clone G734A (Promega) in a 1:2000 dilution, mouse anti-c-Cb1 clone c-15 (Santa Cruz Biotechnology) in a $1: 1000$ dilution, mouse anti-p53 clone DO-7 (Nova Castra Laboratories) in a dilution of $1: 1000$, mouse anti-c$E R B-\mathrm{B}-2 / N E U$ clone CB11 (Novo Castra Laboratories) in a dilution of $1: 1000$, rabbit anti-PML clone 3573 (gift from Dr Kun-San Chang, Department of Molecular Pathology, MD Anderson Cancer Center, USA) in a dilution of 1:1000 and rabbit anti- MAP (Sigma) in a dilution of $1: 2000$. Secondary anti-mouse and anti-rabbit whole antibodies linked to horseradish peroxidase (Amersham) were used diluted 1:1000 and $1: 2000$, respectively.

\section{Flow cytometry analysis}

Cell cycle analysis was performed as described previously (Tavassoli et al., 2002). Briefly, transfected and control cells from a confluent $100 \mathrm{~mm}$ plate were trypsinized and centrifuged for $10 \mathrm{~min}$ at $200 \mathrm{~g}$ together with the medium in which the cells were grown. The cells were washed in PBS and fixed in $5 \mathrm{ml} 70 \%$ ethanol. Cells were stored at $-20^{\circ} \mathrm{C}$ for a minimum of $1 \mathrm{~h}$. Before analysis the cells were centrifuged for $10 \mathrm{~min}$ at $200 \mathrm{~g}$ and the pellet was resuspended in $1 \mathrm{ml}$ staining solution $(40 \mu \mathrm{g} / \mathrm{ml}$ propidium iodide and $500 \mu \mathrm{g} / \mathrm{ml}$ RNAse A in PBS). The cells were incubated for $30 \mathrm{~min}$ at $37^{\circ} \mathrm{C}$ and analysed by flow cytometry using a Becton Dickinson FACSCalibur.

\section{Indirect immunofluorescence staining}

Cells were seeded at a density of $1.8 \times 10^{4}$ and were grown overnight in chamber well slides (Falcon). Slides were washed once with PBS and fixed in acetone for $20 \mathrm{~min}$ at $-20^{\circ} \mathrm{C}$. Fixed cells were washed 3 times in PBS and nonspecific proteins were blocked using 3\% BSA in PBS for $30 \mathrm{~min}$ at room temperature. Cells were incubated for $1 \mathrm{~h}$ with the indicated primary antibodies after which the cells were washed twice for $3 \mathrm{~min}$ with PBS. Cells were then incubated for $1 \mathrm{~h}$ with the secondary antibody at a 1:200 dilution in PBS for anti-mouse or anti-rabbit FIT-C labelled Ig (DAKO), followed by two washes of 3 min in PBS. FIT-C-labelled cells were mounted in DAPI containing mounting solution (DAKO) to stain the nuclei and examined under a fluorescent microscope. Primary antibodies used were: mouse anti-E1A M58 (Pharmingen) diluted $1: 50$ and anti-PML clone diluted $1: 10000$.

\section{Adenovirus amplification and purification}

The following replication incompetent adenoviruses were purified: Ad-E1A (d1324) containing functional E1A, but with complete deletion of E1B and E3 (Yan et al., 1991). As controls we used two mutant E1A: Ad-mut1E1A (d1312) containing a base pair deletion resulting in a nonfunctional E1A, a complete deletion of E1B and E3 and Ad-mut2E1A containing a mutated nonfunctional E1A, deletion of E1B and E3 (Yan et al., 1991). Approximately $1 \times 10^{9} 293 \mathrm{~A}$ cells were infected with different adenovirus constructs. Cells were harvested when a complete cytopathic (CPE) effect was observed, that is $95-100 \%$ of the cells were rounded and 5 $10 \%$ were floating. Cells were lifted from the flask by pipetting gently and collected by centrifuging for $10 \mathrm{~min}$ at $200 \mathrm{~g}$. Purification and titration of the adenovirus was essentially done as described by Graham and Prevec (1991).

\section{MTT assay}

Cells were cultured in 96-well plates at a density of $1.8 \times 10^{4}$ cells per well, the following day cells were infected with adenovirus at a multiplicity of infection (MOI) of 10. Cell survival was measured by MTT assay, 24 and $48 \mathrm{~h}$ after adenoviral infection. MTT assay determines mitochondrial activity, which normally correlates with the number of viable cells in culture. Briefly, $20 \mu 1$ of $5 \mathrm{mg} / \mathrm{ml}$ MTT (3-(4,5dimethylthiazolyl-2)-2.5-diphenyltetrazolium bromide) in PBS was added to each well. Cells were incubated with the MTT compound for $2-4 \mathrm{~h}$ at $37^{\circ} \mathrm{C}$ and $5 \% \mathrm{CO}_{2}$, subsequently $150 \mu \mathrm{l}$ of solubilization solution ( $50 \%$ dimethylformamide, $0.2 \%$ glacial acetic acid, $20 \mathrm{~mm} \mathrm{HCl,} 20 \%$ SDS) was added to each well. The plates were incubated for a further $16-24 \mathrm{~h}$ and the $\mathrm{OD}_{595}$ was measured.

\section{Acknowledgements}

We are grateful to Dr M-C Hung, Department of Molecular and Cellular Oncology, MD Anderson Cancer Center for the E1A vectors, to Prof. William Gullick Department of Biosciences, University of Kent at Canterbury for EGFR antibody and for advice on EGFR expression analysis, Dr Kun-San Chang, Department of Molecular Pathology, MD Anderson Cancer Center for PML antibody and advise on PML analysis. We would like to thank Dr Barry Gusterson, Department of Pathology, University of Glasgow for HN5, Dr Andrew Yeudall, Department of Craniofacial Development, Guy's Dental Institute for HN30 and Dr Stephen Prime, Department of Oral and Dental Science, University of Bristol for $\mathrm{H} 357$ cell lines. MF was supported by a studentship awarded by Guy's, King's and St Thomas's Dental Institute. This work was supported by grants from the Royal Society and European Union (EU).

\section{References}

Alcalay M, Tomassoni L, Colombo E, Stoldt S, Grignani F, Fagioli M, Szekely L, Helin K and Pelicci PG. (1998). Mol. Cell. Biol., 18, 1084-1093.

Askujarvi G. (1979). J. Mol. Biol., 134, 143-158.

Averbuch SD. (2002). Clin. Cancer Res., 8, 1-3.

Borrelli E, Hen R and Chambon P. (1984). Nature, 312, 608612.

Branton PE, Bayley ST and Graham FL. (1985). Biochim. Biophys. Acta, 780, 67-94.

Chang JY, Xia W, Shao R and Hung MC. (1996). Oncogene, 13, 1405-1412.

Chang JY, Xia W, Shao R, Sorgi F, Hortobagyi GN, Huang L and Hung MC. (1997). Oncogene, 14, 561-568.

Chiou SK, Rao L and White E. (1994). Mol. Cell. Biol., 14, 2556-2563.

Davies DE and Chamberlin SG. (1996). Biochem. Pharmacol, 51, 1101-1110.

Duque PM, Alonso C, Sanchez-Prieto R, Lleonart M, Martinez C, de Buitrago GG, Cano A, Quintanilla M and Ramon y Cajal S. (1999). Cancer Gene Ther., 6, 554-563.

Dyck JA, Maul GG, Miller Jr WH, Chen JD, Kakizuka A and Evans RM. (1994). Cell, 76, 333-343.

Faha B, Harlow E and Lees E. (1993). J. Virol., 67, 2456-2465.

Ferguson B, Krippl B, Andrisani O, Jones N, Westphal H and Rosenberg M. (1985). Mol. Cell. Biol., 5, 2653-2661. 
Fogal V, Gostissa M, Sandy P, Zacchi P, Sternsdorf T, Jensen K, Pandolfi PP, Will H, Schneider C and Del Sal G. (2000). EMBO J., 19, 6185-6195.

Frisch SM and Dolter KE. (1995). Cancer Res., 55 5551-5555.

Frisch SM and Mymryk JS. (2002). Nat. Rev. Mol. Cell Biol., 3, 441-452.

Fry DW, Kraker AJ, McMichaE1A, Ambroso LA, Nelson JM, Leopold WR, Connors RW and Bridges AJ. (1994). Science, 265, 1093-1095.

Graham FL and Prevec L. (1991). Methods in Molecular Biology: Gene Transfer and Expression Protocols. Murray EJ (ed). Human Press Inc.: Clifton, NJ, pp 109-128.

de Groot R, Foulkes N, Mulder M, Kruijer W and SassoneCorsi P. (1991). Mol. Cell. Biol., 11, 192-201.

Grooteclaes ML and Frisch SM. (2000). Oncogene, 19, 3823 3828.

He Y, Zeng Q, Drenning SD, Melhem MF, Tweardy DJ, Huang L and Rubin Grandis J. (1998). J. Nat. Cancer Inst., 90, 1080-1087.

Irish JC and Bernstein A. (1993) Laryngoscope, 103, 42-52.

Ishii S, Xu Y, Stratton RH, Roe BA, Merlino GT and Pastan I. (1985). Procl. Natl. Acad. Sci. USA, 82, 4920-4924.

Jensen K, Shiels C and Freemont PS. (2001). Oncogene, 20, 7223-7233.

Kao HT and Nevins JR. (1984). Mol. Cell. Biol., 4, 2792-2810.

Lee WP, Liao Y, Robinson D, Kung HJ, Liu ET and Hung MC. (1999). Mol. Cell. Biol., 19, 8075-8082.

Lill NL, Douillard P, Awwad RA, Ota S, Lupher Jr ML, Miyake S, Meissner-Lula N, Hsu VW and Band H. (2000). J. Biol. Chem., 275, 367-377.

Lowe SW, Jacks T, Housman DE and Ruley HE. (1994). Proc. Natl. Acad. Sci. USA, 91, 2026-2030.

Lowe SW and Ruley HE. (1993). Genes Dev., 7, 535-545.

Ludes-Meyers JH, Subler MA, Shivakumar CV, Munoz RM, Jiang P, Bigger JE, Brown DR, Deb SP and Deb S. (1996). Mol. Cell. Biol., 16, 6009-6019.

Mal A, Poon RY, Howe PH, Toyoshima H, Hunter T and Harter ML. (1996). Nature, 380, 262-265.

Maul GG, Yu E, Ishov AM and Epstein AL. (1995). J. Cell. Biochem., 59, 498-513.

de Melker AA, van der Horst G, Calafat J, Jansen H and Borst J. (2001). J. Cell Sci., 114, 2167-2178.

Mymryk JS. (1996). Oncogene, 13, 1581-1599.

Nishi H, Senoo M, Nishi KH, Murphy B, Rikiyama T, Matsumura Y, Habu S and Johnson AC. (2001). J. Biol. Chem., 276, 41717-41724.

Prudenziati M, Sirito M, van Dam H and Ravazzolo R. (2000). Int. J. Cancer, 88, 943-948.
Rusch V, Baselga J, Cordon-Cardo C, Orazem J, Zaman M, Hoda S, McIntosh J, Kurie J and Dmitrovsky E. (1993). Cancer Res., 53, 2379-2385.

Saha V, Young BD and Freemont PS. (1998). J. Cell. Biochem. Suppl., 30-31, 264-276.

Salomon DS, Normanno N, Ciardiello F, Brandt R, Shoyab M and Todaro GJ. (1995). Breast Cancer Res. Treat., 33, 103-114.

Sartor M, Steingrimsdottir H, E1Amin F, Gaken J, Warnakulasuriya S, Partridge M, Thakker N, Johnson NW and Tavassoli M. (1999). Br. J. Cancer, 80, 79-86.

Sassone-Corsi P and Borrelli E. (1987). Proc. Natl. Acad. Sci. USA, 84, 6430-6433.

Sheikh MS, Carrier F, Johnson AC, Ogdon SE and Fornace Jr AJ. (1997). Oncogene, 15, 1095-1101.

de Stanchina E, McCurrach ME, Zindy F, Shieh SY, Ferbeyre G, Samuelson AV, Prives C, Roussel MF, Sherr CJ and Lowe SW. (1998). Genes Dev., 12, 2434-2442.

Stein RW, Corrigan M, Yaciuk P, WhE1An J and Moran E. (1990). J. Virol., 64, 4421-4427.

Stein R and Ziff E. (1984). Mol. Cell Biol., 4, 2792-2801.

Tavassoli M, Soltaninia J, Rudnicka J, Mashanyare D, Johnson N and Gäken J. (2002). Carcinogenesis, 23, 15691576.

Theodoro JG, Shore GC and Branton PE. (1995). Oncogene, 11, 467-474.

Thomas A and White E. (1998). Genes Dev., 12, 1975-1985.

Tian XX, Chan JYH, Pang JCS, Chen J, He JH, To TSS, Leung SF and Ng HK. (1999). Br. J. Cancer, 81, 994-1001.

Vallian S, Chin K and Chang K. (1998). Mol. Cell. Biol., 18, 7147-7156.

Vallian S, Gäken JA, Trayner ID, Gingold EB, Kouzarides T, Chang KS and Farzaneh F. (1997). Exp. Cell. Res., 237, 371-382.

Weis K, Rambaud S, Lavau C, Jansen J, Carvalho T, CarmoFonseca M, Lamond A and Dejean A. (1994). Cell, 76, 345356.

Whyte P, Buchkovich KJ, Horowitz JM, Friend SH, Raybuck M, Weinberg RA and Harlow E. (1988). Nature, 334, 124-129.

Woodburn JR. (1999). Pharmacol. Ther., 82, 241-250.

Wu WS, Vallian S, Seto E, Yang WM, Edmondson D, Roth S and Chang KS. (2001). Mol. Cell. Biol., 21, 2259-2268.

Yan DH, Chang LS and Hung MC. (1991). Oncogene, 6, 343-345.

Yeudall WA, Jakus J, Ensley JF and Robbins KC. (1997). Mol. Carcinog., 18, 89-96.

Yu D, Matin A, Xia W, Sorgi F, Huang L and Hung MC. (1995). Oncogene, 11, 1383-1388. 